\title{
Policy Aspects of Service-Based Governance in Secondary Educational Institutions of Vietnam
}

\author{
The-Thang Nguyen, Thi-Phuong Ngo, Le Thi - Thuy Phuong, Ngọc- Diep Hoang
}

\begin{abstract}
This paper is an overview of issues related to state management of general education institution governance with an approach of educational services, which focuses on analyzing some aspects, including educational services, governance of public education institutions and generalization of policies on the governance of public education institutions which have been enacted at central and local levels. The article also provides judgments made by principals/vice-principals of public education institutions on legal documents' practical value for public educational institutions' governance in educational services. The results of conceptual and policy analysis and practical research are the basis for improving the effectiveness of public educational institutions' governance in educational services' approach these days.
\end{abstract}

Keywords: Educational Service, General Education Institution

\section{INTRODUCTION}

From the late 1970s and early 80s, a new public management model appeared in OECD countries and gradually became more common. Initially applied in businesses and had superior characteristics such as an emphasis on efficiency, efficiency, quality, transparency and accountability (Pollitt \& Bouckaert, 2004), many public organizations quickly apply this model to create public services products.

In Vietnam, many public institutions are now on the same process, including education, when many more private educational institutions are established and operated under a new management model adapted from enterprises. Therefore, education is now regarded as a service or "educational services". On the one hand, it brings more choices and learning opportunities for "customers" who are learners. On the other hand, it also brings risks for learners and challenges for the entire education system. That context and the shift from a centralized management system to a socialist-oriented market mechanism have required the state management of

Manuscript received on April 10, 2021.

Revised Manuscript received on April 19, 2021.

Manuscript published on April 30, 2021.

*Correspondence Author

The-Thang Nguyen*, The Vietnam National Institute of Educational Sciences, Hanoi, Vietnam. Email: thangvcl@gmail.com

Dr. Thi- Phuong Ngo, Senior lecturer, Faculty of Social Sciences, Tay Bac University. Hanoi, Vietnam.

Le Thi - Thuy Phuong, The Vietnam National Institute of Educational Sciences, Hanoi, Vietnam.

Ngọc- Diep Hoang, The Vietnam National Institute of Educational Sciences, Hanoi, Vietnam.

(C) The Authors. Published by Blue Eyes Intelligence Engineering and Sciences Publication (BEIESP). This is an open access article under the CC BY-NC-ND license (http://creativecommons.org/licenses/by-nc-nd/4.0/) Governance.

education to change in terms of quality, efficiency, and transparency.

This article presents an overview of educational services and institution governance, and examines the legal basis for general school governance as an aspect of state management of education and illustrated some practical research results on school governance in Hanoi and Ho Chi Minh City.

\section{Educational services}

Educational services are "services that facilitate the implementation of education policies, achieve policy goals, and promote the education system's effectiveness" (FRN, 2004). The goals of educational services are to (1) create suitable conditions for the implementation of educational policies on educational programs, improve teachers' teaching capacity, and create a positive learning environment for students, promoting regular and lifelong learning; (2) ensure the efficiency and quality of the whole system's operation.

In Vietnam, "educational services" has not been defined directly and officially but has been mentioned in a number of important documents. Decree 16/2015 / ND-CP dated February 14, 2015, of the Government regulating the autonomy mechanism of public institutions stating "public -provided services" services in the sectors of education training; vocational training; medical; culture, sports and tourism; media and press information; science and technology; economics and others" ${ }^{1}$. The Education Law 2019 "encourages organizations and individuals to participate and provide quality education services to meet the lifelong learning needs of learners", and at the same time identify one of the sources of income for education is "income from education, training, science and technology services; services to serve and support educational activities of educational institutions "and require" public implementation of the costs of education and training services $" 2$.

\section{Educational institution governance}

Governance of the education system is about ensuring the efficiency, transparency and accountability of educational services, thereby improving organizational performance (Lewis et al., 2009). In Vietnam, general school governance is content of state management of education, "is the process of building orientations, regulations, and operational plans in schools; organizing teaching activities, educating students

1 Clause 2, Article 3, Decree 16/2015 / ND-CP dated February 14, 2015 of the Government regulating the autonomy mechanism of public organizations

2 Clause 1 Article 46, Article 95, Article 99 of the Law on Education No. 43/2019 / QH14 dated June 14, 2019.

Published By:

\& Sciences Publication

(C) Copyright: All rights reserved.

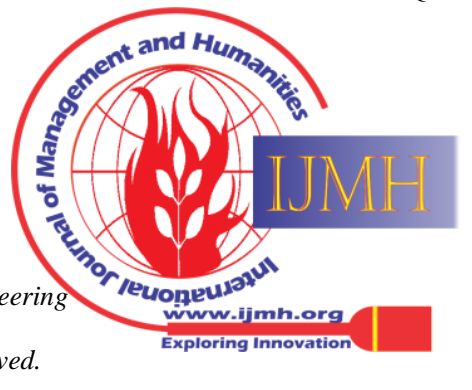


through mobilizing and using resources, monitoring and evaluating on the basis of autonomy and accountability to develop the school according to the mission, vision and educational goals of the school" ${ }^{3}$. School governance includes six activities: (1) developing school plans; (2) governance the teaching and educating students; (3) school personnel governance; (4) organizational and administrative governance; (5) school financial governance; (6) governance of the quality of education ${ }^{4}$. These activities are evaluated according to 14 specific criteria.

As required by educational innovation, general education needs (1) changes in school management and governance towards learners' competency, quality standards, publicity, and management mechanisms are consistent with the socialist-oriented market economy; (2) changes in the decentralization of education management from central to local according to the principle of unification of power, with close assignment and coordination among ministries and state agencies in the exercise of legislative powers, executive and exercise responsibility and authority. That enables schools to establish school councils, have autonomy in many aspects of the school's activities associated with accountability; (3) consideration for the socialization of education to create more resources for educational development to meet the needs of the labor market and the needs of learners.

\section{Legals of school governance in terms of a service-based approach}

\section{Legals issued by central agencies}

Although there are no documents issued by the central management agency to regulate the educational-serviced governance at general education institutions specifically, some relevant contents are mentioned in different documents.

- Decree No. 16/2015 / ND-CP dated February 14, 2015, of the Government regulating the autonomy mechanism of public service providers.

- Decision No. 439 / QD-TTg dated 10/4/2017 Establishment of the State Steering Committee on reform of the operating mechanism of public service institutions.

- Resolution No. 19-NQ / TW The Sixth Conference of the Central Executive Committee Session XII dated October 25 , 2017, on continuing to renovate the organizational and management system, improve the quality and efficiency of the public service institutions have determined "to promote socialization, ... mobilize... all resources for investment in the healthy development of the public service market ..." ... Develop the public service market and strongly attract all economic sectors to participate in the development of public services".

- Implementing Resolution No. 08 / NQ-CP, the Minister of Education and Training promulgates Decision No. 1233 / QD-BGDĐT with an action plan to meet the task of continuing to renew the organizational and management system. In order to improve the quality and efficiency of operations of the public service providers under the Ministry and throughout the education sector. [11]

3 Clause 8 Article 3 of Circular 14/2018 / TT-BGDĐT

4 Article 5, Circular 14/2018/TT-BGDĐT
- Decree No. 69/2008 / ND-CP regulates the responsibilities of the institutions implementing socialization and state management for service providers in the field of socialization. [12]

- To guide the implementation of Decree No. 69/2008 / ND-CP, the Ministry of Finance promulgates Circular No. 135/2008 / TT-BTC detailing the scope, subjects, conditions to be beneficiaries of the policy, the implementation principles, the sources of revenue of the socialized institutions, the responsibilities the State management of these institutions. [14]

- Circular No. 14/2019 / TT-BGDĐT guiding the formulation, appraisal, and issuance of economic technical norms and method of setting education and training service prices applicable in the field of education and training. In which, specifies the economic - technical norms and components on labor norms, equipment and supplies norms, and determines the price of training services based on economic - technical norms as follows:

\section{Service price $=$ Salary costs + Material costs + Management costs + Depreciation/amortization costs of assets (investment accumulation) + Other expenses, funds}

\section{The documents issued by local authorities}

On the basis of the documents promulgated by the central government, the local authorities shall formulate a system of legal documents guiding the implementation of the policy on general school governance based on educational service approach and local conditions. Some documents issued by the Hanoi People's Committee and Ho Chi Minh City People's Committee to provide the guidelines and policies from the central level as follows:

- Resolution No. 03/2018 / NQ-HDND stipulates the additional payment of income based on the work performance of cadres, civil servants and public employees in each unit that the institutional manager take responsibility for. The adjustment coefficient of income increase for the implementation of the specific mechanism will increase gradually in the period of 2018 2020, up to a maximum of 0.6 times in 2018 to a maximum of 1.8 times compared with the salary according to ranks and positions, this coefficient within the scope specified in Resolution 54/2017 / QH14. [15]

- Resolution No. 06/2019/NQ-HDND dated 8/7/2019 regulates the increase in tuition fees for general public education, except for high-quality public education institutions, which specifies collection rates by the locality: urban, rural and mountainous communes. The additional tuition fees are used partly to implement salary reform according to regulations. The rest is used for annual education expenses. This content is also specified in Resolution No. 05/2018 / NQ-HDND dated July 5, 2018, of the People's Council of Hanoi.[16]

Published By: Blue Eyes Intelligence Engineering \& Sciences Publication (C) Copyright: All rights reserved. 
Besides, there are documents promulgated by localities that should be mentioned:

- Decision No. 11/2015 / QD-UBND dated May 19, 2015, of the People's Committee of Hanoi on stipulating policies to encourage socialization of fields, including education and training in Hanoi to implement the Decree No. 69/2008 / ND-CP dated 30/5/2008.

- Plan No. 97 / KH-UBND ${ }^{5}$ dated 20/5/2016 of the Hanoi People's Committee requires relevant departments, agencies to identify specific work contents, progress and deadline. Completing and at the same time building a coordination mechanism between departments, branches and People's Committees of districts, towns to implement the implementation of Decree No. 16/2015 / ND-CP of the

- Decision No. 11/2015 / QD-UBND dated May 19, 2015, issued by the People's Committee of Hanoi, providing regulations on policies to encourage socialization in a number of fields, including education and training in locals.

\section{METHODS}

This study is conducted by combined the results of qualitative and quantitative research on general education institution governance on the service-based approach. Qualitative research generalizes and identifies changes in state management policies through an understanding of governance for public services generally and in general education institutions particularly. The survey used Disagree" to "Level 5 - Strongly Agree". Respondents are principals and vice-principals of general education institutions in Hanoi and Ho Chi Minh City. Sample features. Respondents are 36 principals, vice-principals of 36 junior high schools, high schools and multi-level high schools in Hanoi and Ho Chi Minh City. More than half (61.11\%) of the total staff participating in the survey have working experience $>20$ years. $72.22 \%$ have management experience $>5$ years.

\section{RESULTS AND DISCUSSION}

\section{At the schools}

Table 1 below summarizes how principals assessed the aspects of educational services in general education institutions. All content is assessed at around 4, showing that managers have a positive perspective on educational services at general education institutions.

Table 1 the opinions of the principals about educational services in the general educational institutions

\begin{tabular}{|c|l|c|}
\hline No & \multicolumn{1}{|c|}{ Statements } & Mean \\
\hline 1 & $\begin{array}{l}\text { Mobilize the social sources to improve the total quality of } \\
\text { education }\end{array}$ & 4.28 \\
\hline 2 & A kind of public service to meet the demand of learners & 4.28 \\
\hline 3 & Meet the targets of general education regulated by the laws & 4.22 \\
\hline 4 & Improve the people's knowledge and culture of the society & 4.22 \\
\hline
\end{tabular}

\footnotetext{
${ }^{5}$ Plan to implement Decree No. 16/2015 / ND-CP dated February 14, 2015 of the Government regulating the autonomy mechanism of public service agencies under the management of the city. Available from https://vanbanphapluat.co/ke-hoach-97-kh-ubnd-trien-khai-16-2015-nd-cpco-che-tu-chu-don-vi-su-nghiep-ha-noi- 2016
} Government.[13] questionnaires with a 5-level scale from "Level 1 - Strongly

\begin{tabular}{|c|l|c|}
\hline 5 & $\begin{array}{l}\text { It is a product of the supply and demand of the market } \\
\text { mechanism }\end{array}$ & 4.22 \\
\hline 6 & $\begin{array}{l}\text { It is the change of state management to develop the quality } \\
\text { of general education }\end{array}$ & 4.06 \\
\hline 7 & $\begin{array}{l}\text { Improve community supervision with school educational } \\
\text { activities }\end{array}$ & 3.97 \\
\hline 8 & $\begin{array}{l}\text { Change the responsibilities and interests of the parties } \\
\text { related to general education }\end{array}$ & 3.86 \\
\hline
\end{tabular}

Legal documents on school governance on service-based approach

Table 2 shows managers' satisfaction level about the legal document system on school governance on service-based approach. Nearly $42 \%$ of managers are satisfied with the system of regulations and guidelines for educational institutions, in which the percentage of managers who feel very satisfied is $>11 \%$. More than half of the managers (> $58 \%$ ) are not satisfied with the system of regulations and guidelines for governance in schools, of which nearly half (> $47 \%$ ) feel that they are received at the average level, which means that the new documents only cover basic governance activities in high schools.

Table 2. The system of legal documents on general school governance towards education services

\begin{tabular}{|l|l|l|}
\hline Levels & No & \% \\
\hline Not at all satisfied & 0 & 0.00 \\
\hline Slightly satisfied & 4 & 11.11 \\
\hline Moderately satisfied & 17 & 47.22 \\
\hline Very Satisfied & 11 & 30.56 \\
\hline Extremely satisfied & 4 & 11.11 \\
\hline Total & 36 & 100.00 \\
\hline
\end{tabular}

Table 3 below shows the managers' comments on the correlation between activities governing general schools as prescribed in legal documents promulgated by central management agencies and management activities practically in general schools. All comments were above the "mean" level (between 3.33 and 3.47), showing that the document system issued by the central management agency did not provide a fully legal basis, not yet stated have clear requirements on how to organize, operate, technical requirements and have not yet instructed to solve problems arising in the direction, administration and organization of general school governance towards education services.

Table 3. The effectiveness of school governance documents issued by central authorities

\begin{tabular}{|c|l|c|}
\hline No & Policies issued by the central agencies & Mean \\
\hline 1 & Guaranteed for administrative performance & 3.47 \\
\hline 2 & Specifies the requirements for how the governance should be & 3.47 \\
\hline 3 & Specified technical requirements of governance & 3.42 \\
\hline
\end{tabular}

Published By:

Blue Eyes Intelligence Engineerin

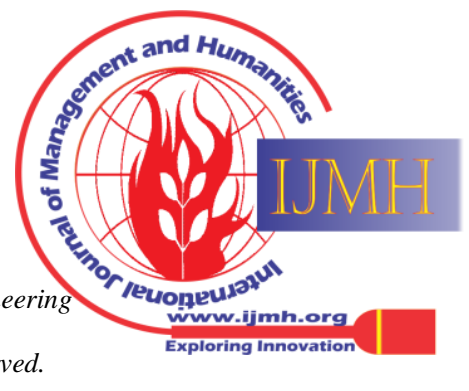




\begin{tabular}{|c|l|c|}
\hline 4 & $\begin{array}{l}\text { Have clearly expressed the direction for the implementation } \\
\text { of governance }\end{array}$ & 3.36 \\
\hline 5 & $\begin{array}{l}\text { Instructions and timely answers arise of educational services } \\
\text { in the locals }\end{array}$ & 3.33 \\
\hline
\end{tabular}

Table 4 shows that the general school governance' documents issued by the local authorities are more appreciated than those issued by the central agencies, but only above the average (in the range of 3.47 to 3.61), which means that these documents only provide basic regulations and guidelines, specifier the documents from the central level, do not provide adequate guidance for implementation and not consistent with the local characteristics for this activity.

Table 4. The effectiveness of local documents on governance at general education institutions

\begin{tabular}{|l|l|c|}
\hline No & The documents issued by local authorities & Mean \\
\hline 1 & $\begin{array}{l}\text { Concretize governance requirements from central } \\
\text { documents }\end{array}$ & 3.61 \\
\hline 2 & $\begin{array}{l}\text { Guaranteed for administrative performance according to } \\
\text { local conditions }\end{array}$ & 3.56 \\
\hline 3 & $\begin{array}{l}\text { Understand obviously, easily when directing the } \\
\text { implementation of governance }\end{array}$ & 3.47 \\
\hline 4 & $\begin{array}{l}\text { Full instructions and answers when implementing } \\
\text { governance }\end{array}$ & \\
\hline
\end{tabular}

\section{CONCLUSION}

Education increasingly tends to be seen as a type of service, so the governance of educational institutions towards educational services is a practical requirement. The government, ministries, branches and localities have issued a system of state management documents for these governance activities, although not sufficiently and with proper focus. Because there are many different interpretations leading to the lack of synchronization and efficiency in the school governance process, the unification into the concept or view of educational services should be specified in the parallel legal documents. In parallel with the review and supplementation of the missing contents to help the Government and the Ministry of Education and Training of schools towards education services. . A full system of legal documents is also an important legal framework for educational state agencies at all levels to implement well education policies.

Academically, the shift of concepts represents the development of a science of educational management in general and management of general education institutions in particular. At a higher level, such development requires the content and scope of state management of general education institutions to change according to the general trend.

In terms of policy, the existing documents have initially shaped the school management activities and related elements in the direction of educational service governance. However, to align with the trend of the development of education management in the world as well as the demand for education in the country, it is necessary to systematize the direct and formulate appropriate policies for the management

current documents and issue additional documents for governance to become the driving force in solving problems and freeing up resources for general education development in the coming time.

\section{REFERENCES}

1. The Decree regulates the autonomy mechanism of public organizations. Available from https://thuvienphapluat.vn/van-ban/bo-may-hanh-chinh/Nghi-dinh-162015-ND-CP-co-che-tu-chu-cua-don-vi-nghiep-cong- lap-266548.aspx

2. The decision to set up the State Steering Committee on renewing the operating mechanism of public organizations. Available from http://congbao.chinhphu.vn/noi-dung-van-ban-so-439-qd-ttg-22695

3. The Resolution of the Sixth Conference of the Central Committee, Session XII, on continuing to renovate the organizational and management system and improve public service delivery organizations' quality and efficiency. Available from: https://thuvienphapluat.vn/van-ban/bo-may-hanh-chinh/Nghi-quyet-19NQ-TW-2017-nang-cao-chat-luong-hieu-qua-hoat-dongthe-license-of-the-industry-company-365583.aspx

4. The Government's Resolution on the government's action plan to implement Resolution No. 19-NQ / TW dated October 20, 2017, of the Sixth Conference of the Central Committee XII on continuing to innovate. Organizational and management system improves the quality and efficiency of public units. Available from http://vanban.chinhphu.vn/portal/page/portal/chinhphu/hethongvanban ?class_id=509\&_page $=1$ \&mode=detail\&document_id=192801

5. Decree on policies to encourage socialization of activities in education, vocational training, health, culture, sports, the environment. Available from

https://thuvienphapluat.vn/van-ban/Tai-nguyen-Moi-truong/Nghi-dinh69-2008-ND-CP-chinh-sach-khuyen-khich-xa-hoi-hoa-doi-voiactivities-in-spirit-in-the-field-to-listen-to-the-economy-the-new-sports -sports-66553.aspx activities

6. Circular guiding the Government's Decree No. 69/2008 / ND-CP dated May 30, 2008, on policies to encourage socialization of activities in education, vocational training and health, culture, sports, the environment. Available from http://vanban.chinhphu.vn/portal/page/portal/chinhphu/hethongvanban ?class_id=1\&_page=1\&mode=detail\&document_id=83089

7. Circular guiding the formulation, appraisal and promulgation of economic - technical norms and method of setting education and training service prices applicable in education and training. Available from

https://thuvienphapluat.vn/van-ban/tai-chinh-nha-nuoc/Thong-tu-14-20 19-TT-BGDDT-phuong-phap-xay-dung-gia-dich-vu-giao-ducknife-tao-424613.aspx

8. The Resolution promulgates regulations on additional income spending for cadres, civil servants, public employees in the state management sector, political organizations, socio-political organizations, and public organizations. Established by the city and managed by the People's Council of Ho Chi Minh City, term IX, at the seventh session. Available from

https://thuvienphapluat.vn/van-ban/bo-may-hanh-chinh/Nghi-quyet-032018-NQ-HDND-chi-thu-nhap-tang-them-cho-can-bo-cong-

Happy-Ho Chi Minh-Ho Chi Minh City-378314.aspx

9. The Resolution regulates the tuition fee for preschool education, the public high school of Hanoi city, and the North Thang Long Economic and Technical Secondary School's tuition fee rate, the Intermediate School Hanoi's IT engineering school year 2019-2020. Available from https://luatvietnam.vn/giao-duc/nghi-quyet-06-2019-nq-hdnd-ha-noi-m uc-thu-hoc-phi-doi-voi-giao-duc-pho-thong-cong- lap-175565-d2.html

10. The Resolution regulates the fee collection for preschool education, public high school education in Hanoi city and the tuition fee rate for North Thang Long Economic and Technical Secondary School, Intermediate School Hanoi informatics engineering school year 2018-2019. Available from https://luatvietnam.vn/giao-duc/nghi-quyet-05-2018-nq-hdnd-ha-noi-m uc-thu-hoc-phi-doi-voi-cac-truong-cong-lap-165194- d2.html

\section{Published By:}

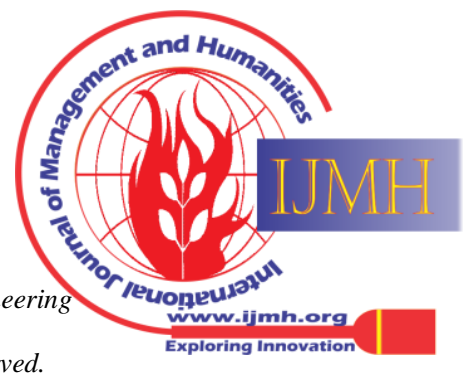

Blue Eyes Intelligence Engineerin \& Sciences Publication (C) Copyright: All rights reserved. 
11. https://thuvienphapluat.vn/van-ban/Bo-may-hanh-chinh/Quyet-dinh-12 33-QD-BGDDT-2018-nang-cao-chat-luong-hoat-dong-cua-cac-don-visu-nghiep-cong-lap-402072.aspx

12. http://vanban.chinhphu.vn/portal/page/portal/chinhphu/hethongvanban ?class_id=1\&_page $=1 \&$ mode $=$ detail\&document_id $=73157 \#: \sim:$ text $=\mathrm{N}$ gh\%E1\%BB\%8B\%20\%C4\%91\%E1\%BB\%8Bnh\%20s\%E1\%BB\%91 \%2069\%2F2008,h\%C3\%B3a\%2C\%20th\%E1\%BB\%83\%20thao\%2C \%20m\%C3\%B4i\%20tr\%C6\%B0\%E1\%BB\%9Dng\&text=L\%C4\%A9n h\%20v\%E1\%BB\%B1c\%20x\%C3\%A3\%20h\%E1\%BB\%99i\%20h\%C3 \%B3a,d\%E1\%BB\%A5c\%20th\%E1\%BB\%83\%20thao\%3B\%20m\%C3 \%B4i\%20tr\%C6\%B0\%E1\%BB\%9Dng.

13. https://m.thuvienphapluat.vn/van-ban/tai-chinh-nha-nuoc/Thong-tu-13 5-2008-TT-BTC-khuyen-khich-xa-hoi-hoa-hoat-dong-giao-duc-day-ng he-y-te-van-hoa-the-thao-moi-truong-huong-dan-Nghi-dinh-69-2008-N D-CP-84990.aspx

14. https://thuvienphapluat.vn/van-ban/Tai-chinh-nha-nuoc/Thong-tu-14-2 019-TT-BGDDT-phuong-phap-xay-dung-gia-dich-vu-giao-duc-dao-tao -424613 .aspx

15. https://thuvienphapluat.vn/van-ban/Bo-may-hanh-chinh/Nghi-quyet-03 -2018-NQ-HDND-chi-thu-nhap-tang-them-cho-can-bo-cong-chuc-vien -chuc-Ho-Chi-Minh-378314.aspx

16. https://luatvietnam.vn/giao-duc/nghi-quyet-06-2019-nq-hdnd-ha-noi-m uc-thu-hoc-phi-doi-voi-giao-duc-pho-thong-cong-lap-175565-d2.html

\section{AUTHORS PROFILE}

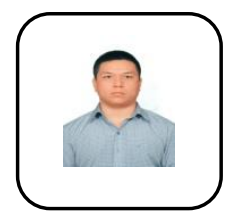

The - Thang Nguyen, is a senior researcher of the Vietnam National Institute of Educational Sciences, the Ministry of Education and Training of Vietnam. He has experiences in varied educational sectors. Dr Thang is also a key member of many national research projects. The author of academic articles published both local and ISI/ Scopus indexed journals.

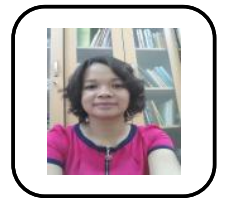

Thi- Phuong Ngo, With over 20 years of teaching and researching in university, Dr. Thi- Phuong Ngo is a senior lecturer, Faculty of Social Sciences, Tay Bac University. She is an inspirational and dedicated teacher regarded by many of her students and colleagues.

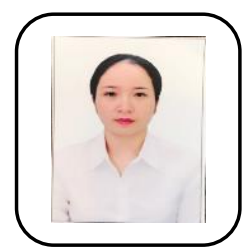

Thuy, is a researcher of the Vietnam National Institute of Educational Sciences. Thuy has manifold experiences in educational economics and educational policies. She also has quite a few experiences in working with local and central authorities in the education sector.

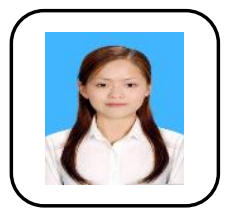

Ngọc- Diep Hoang, Graduated from the National Economics University, Diep had worked in a state enterprise that proved how intelligent and clever she had been. As a researcher of the Vietnam National Institute of Educational Sciences, Diep is interested in educational policies and educational economics.

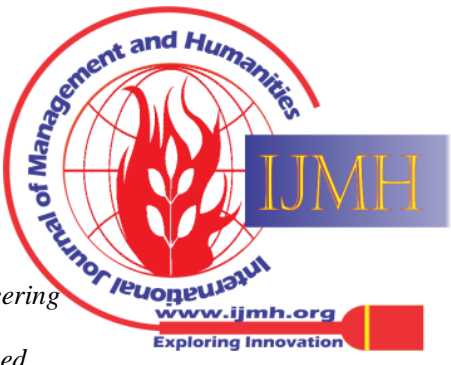

